\title{
Contribution to the Macrophytic Typology of Belgian Reference Watercourses
}

\author{
Daniel Galoux, ${ }^{1}$ Frédéric Chérot, ${ }^{1}$ Francis Rosillon, ${ }^{2}$ and Khadija Sossey-Alaoui ${ }^{2}$ \\ ${ }^{1}$ Département de l'Étude du Milieu Naturel et Agricole (DEMNA), Direction Générale de l’Agriculture, \\ des Ressources Naturelles et de l'Environnement, Service Public de Wallonie, avenue Maréchal Juin 23, 5030 Gembloux, Belgium \\ ${ }^{2}$ Département des Sciences et Gestion de l'Environnement, Université de Liège, avenue de Longwy 185, 6700 Arlon, Belgium \\ Correspondence should be addressed to Daniel Galoux; d.galoux@skynet.be
}

Received 28 October 2014; Accepted 3 February 2015

Academic Editor: Baohong Zhang

Copyright (C) 2015 Daniel Galoux et al. This is an open access article distributed under the Creative Commons Attribution License, which permits unrestricted use, distribution, and reproduction in any medium, provided the original work is properly cited.

\begin{abstract}
The objective of the study is to create a typology of macrophytes for the reference watercourses of the Meuse River catchment basin in Wallonia as a step towards the implementation of the European Water Framework Directive. The 50 sites studied are the object of a physicochemical and environmental characterization followed by a floristic survey (phanerogams, mosses, liverworts, and macroalgae). Six clusters of watercourses with their characteristic species are highlighted by two-way clustering and indicator species. The abundance of phanerogams in some watercourses of the Arden region is not only linked to light intensity but also depends on the degree of slope and the nature of the geological substrate.
\end{abstract}

\section{Introduction}

The interest in using macrophytes to assess the ecological quality of aquatic environments is underlined by many European authors, including Kohler [1, 2], Newbold and Holmes [3], Haslam [4], and Haury and Peltre [5].

Research regarding indicative species (auto-ecological method) and indicative plant communities (synecological method) has been carried out in detail during the last 40 years and several macrophytic indexes (Holmes et al. [6], Haury et al. [7], and Schneider and Melzer [8]) have been proposed to assess the quality of watercourses.

In Western Europe, macrophytic typologies were established by Butcher for Britain [9], by Holmes et al. for England, Wales, and Scotland [10], by Grasmück et al. for French Lorraine [11], by Chatenet et al. for French Limousin [12], and by Sossey-Alaoui for Luxemburg [13]. The recent work of Sossey-Alaoui and Rosillon [14] analysed a set of plant data coming for the entire watercourses monitoring network of the Wallonia Region. All these works included impacted and nonimpacted watercourses.

The Water Framework Directive 2000/60/CE [15] requires the assessment of the observed state of watercourses compared to nonimpacted, pristine, or almost pristine corresponding reference conditions. This implies an environment with very low pressures, without the effects of major industrialization, urbanization, or intensification of agriculture and with only very minor modifications of physicochemistry, hydromorphology, and biology. It requires the drawing up of selection criteria related to all the pressures affecting the watercourses.

In Europe, watercourses have suffered for centuries from heavy anthropogenic pressure, and finding reference sites is a difficult work. For example, Denmark [16], Germany [17], and Poland [18] were forced to rely on a restricted number of reference watercourses to elaborate their macrophytic typology.

The objectives of this study are to describe the macrophytic communities of Walloon reference streams, selected according to pressure criteria [20], and to identify the main factors influencing the macrophytic distribution in pristine or almost pristine environments.

Our work focuses on phanerogams, bryophytes, and macroalgae, and environmental factors such as slope, shading, the spring and site altitude, the land cover of the banks, their width, and geological stages and substrates. 
(a)

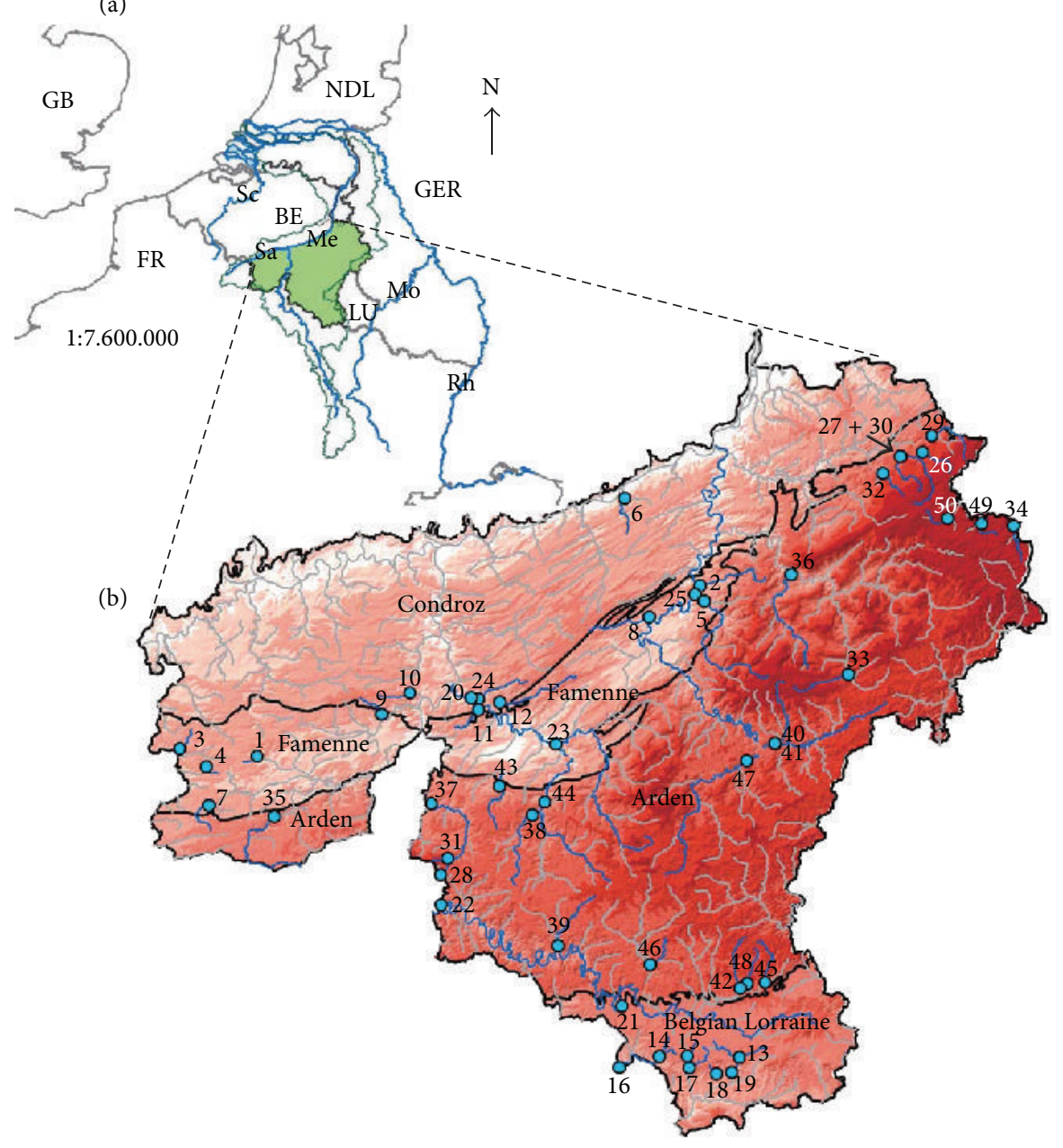

Scale $1: 1000.000$

$\begin{array}{ll}\square<90 \mathrm{~m} & \square 293 \mathrm{~m}-368 \mathrm{~m} \\ \square 90 \mathrm{~m}-156 \mathrm{~m} & \\ \square & 368 \mathrm{~m}-443 \mathrm{~m} \\ 156 \mathrm{~m}-221 \mathrm{~m} & 443 \mathrm{~m}-528 \mathrm{~m} \\ 221 \mathrm{~m}-293 \mathrm{~m} & 528 \mathrm{~m}-693 \mathrm{~m} \\ \square \text { Waterbodies } & \square \text { Study area } \\ \square \text { Meuse catchment basin } & \square \text { Countries }\end{array}$

$\begin{array}{ll}\text { BE: Belgium } & \text { Me: Meuse } \\ \text { FR: France } & \text { Mo: Moselle } \\ \text { GB: Great Britain } & \text { Rh: Rhine } \\ \text { GER: Germany } & \text { Sa: Sambre } \\ \text { LU: Luxemburg } & \text { Sc: Scheldt } \\ \text { NDL: The Netherlands } & \end{array}$

FIgURE 1: Study area in Western Europe (a) and location of the 50 sites in Wallonia (b). See Figure 4(b) for the reference sites codes.

\section{Material and Methods}

2.1. Location of Analysed Sites. The region of Belgium (Wallonia) where the vegetation inventories were taken is shown in Figures 1(a) and 1(b). The studied watercourses all belong to the river catchment basin of the Meuse and are located south and east of the rivers Sambre and Meuse. The Walloon reference sites are restricted to these areas. There are no reference sites in the Limoneuse region north of the Sambre and the Meuse.

The locations of the 50 sites studied are shown in Figure 1(b). The correspondence between the number coding the reference sites and the name of the watercourse is given in Figure 4(b).

The Belgian climate is temperate due to the influence of the Atlantic Ocean. It is characterized by fresh and wet summers and mild and rainy winters. The climatic characteristics of the natural regions of the study area are given in Table 1.

2.2. Selection of Reference Sites and Reference Conditions. This work concerns 50 sites and 49 different watercourses. Two sites, distant $35 \mathrm{~km}$ off, were sampled in two distinct natural regions in the Semois. The selection of the sites is made in accordance with the following parameters of the upstream catchment basin [20]: (1) intensive agriculture (reference: $<20 \%$ ), (2) urbanized area (reference: $<4 \%$ ), (3) density of the bovine population (reference: $<1.5$ animal unit/ha), (4) presence of riparian vegetation (reference: on $>50 \%$ of the length of the site), (5) lateral continuity between river and riparian vegetation either not or not greatly interrupted (aerial photographs), (6) hydromorphological index "QUALPHY" 
TABLE 1: Climatic characteristics of the four natural regions (Source: Bulletin of Royal Meteorological Institute of Belgium-period 19812010).

\begin{tabular}{lcccc}
\hline & Condroz & Famenne & Arden & Lorraine \\
\hline $\begin{array}{l}\text { Mean annual } \\
\text { temperature } \\
\left({ }^{\circ} \mathrm{C}\right)\end{array}$ & 13,6 & 14,3 & 11,9 & 13,0 \\
$\begin{array}{l}\text { Mean annual } \\
\text { rainfall (mm) }\end{array}$ & 875 & 860 & 1284 & 1109 \\
$\begin{array}{l}\text { Number of } \\
\text { dried months }\end{array}$ & 0 & 0 & 0 & 0 \\
\hline
\end{tabular}

(reference >40) [21], (7) no aquaculture directly connected to the stream near the site, and (8) no source of direct pollution from the physicochemical and chemical quality points of view. The highest values admitted in the reference sites are for orthophosphates: $0.040 \mathrm{mg} / \mathrm{L} \mathrm{P}_{-} \mathrm{PO}_{4}{ }^{3-} \mathrm{mg} / \mathrm{L}$, ammoniacal nitrogen: $0.037 \mathrm{mg} / \mathrm{L} \mathrm{N}-\mathrm{NH}_{4}{ }^{+} / \mathrm{L}$, conductivity: $394 \mu \mathrm{S} / \mathrm{cm}$, presence of synthetic pollutants (following the rules of the Walloon authority-AGW 12/09/2002). The sites must be without risk (ecological and chemical excluding polycyclic aromatic hydrocarbon-PAH). The selection criteria are identical across the entire catchment basin and the upper part of the selected streams must be considered as references. All these conditions are mandatory for a site to be included in the dataset.

2.3. Floristic Data. The macrophytic taxa included in the analyses are the phanerogams, the bryophytes (e.g., mosses and liverworts), the main macroalgae, and a lichen. The identification was performed at the species level in the case of phanerogams (Lambinon et al. [22]), bryophytes (Smith [23] and Siebel and During [24]), and algae (John et al. [25]). Since the species identification of some macroalgae requires the presence of reproductive organs, we limited ourselves to the genus level for some taxa (Batrachospermum sp., Mougeotia sp., Spirogyra sp., and Vaucheria sp.).

2.4. Floristic Survey. Plant surveys were carried out between May 15 and August 15 (2005 to 2011) using the protocol of the Macrophyte Biological Index for rivers (France) [26]. The length of the studied water sections is 100 meters. The estimation of coverage is carried out by measuring the stretch area of the surveyed watercourse and then by estimating for each species the percentage of its coverage. The coverage includes five classes of abundance (class $1:<0.1 \%$, class 2: from 0.1 to $1 \%$, class 3 : from 1 to $10 \%$, class 4 : from 10 to $50 \%$, and class 5: from 50 to $100 \%)$. The estimation of plant cover was made for the riverbed and margins as a whole.

The classes of abundance are so broad that the seasonal variability becomes insignificant.

2.5. Physicochemical and Environmental Parameters. The environmental parameters measured or estimated for the site are

(1) the local slope, calculated for a difference in altitude of $15 \mathrm{~m}$ in three categories: medium slope (0.5-7.5\%), strong slope (from $7.5 \%$ to $20 \%$ ), and extremely strong slope (>20\%);

(2) the altitude of the spring in four categories: medium altitude (200-299 m), high altitude (300-399 m), very high altitude (400-499 m), and extremely high altitude $(\geq 500 \mathrm{~m})$;

(3) the altitude of the site in four categories: low altitude (100-199 m), medium altitude (200-299 m), high altitude (300-499 m), and extremely high altitude $(\geq 500 \mathrm{~m})$;

(4) the land cover of the banks (both sides) in six categories: coniferous forest, deciduous forest, meadow and coniferous forest, deciduous and coniferous forest, and meadow;

(5) the shading in three categories: sunlit, moderately sunlit, shady;

(6) the dominant geology of the river catchment area upstream from the site with six categories defined in Table 2;

(7) the substrate in four categories: sand and boulder, shale, boulder, and bedrock;

(8) the width of the site in four categories: small brooks $(0-5 \mathrm{~m}$ ), brooks (from 5 to $10 \mathrm{~m}$ ), rivers (from 10 to $20 \mathrm{~m})$, and large rivers $(\geq 20 \mathrm{~m})$.

The land cover, the shading, and the substrate were estimated and the width was measured in the field; the others parameters were established on the map.

The main characteristics (land cover and altitude) of the Walloon natural regions have been provided in a previous article [14].

The physicochemical parameters analysed are total alkalinity (French degree), conductivity (micro siemens/cm), calcium (mg/L), magnesium (mg/L), orthophosphates (mgP/L), ammoniacal nitrogen $(\mathrm{mgN} / \mathrm{L})$, nitrites $(\mathrm{mgN} / \mathrm{L})$, nitrate nitrogen $(\mathrm{mgN} / \mathrm{L})$, and $\mathrm{pH}$. The results (annual medians) are derived from analyses carried out by the ISSEP (Scientific Institute of Public Service) eight times per year and are shown in Table 3.

2.6. Methods of Analysis. Multiple factorial analysis (MFA) of the three tables (physicochemistry, environment, geology, and land occupation) is used to characterize the sites. The MFA includes principal components analysis of the physicochemical results and multiple correspondence analysis of the other variables (Escoffier and Pages [27]).

The $k$-means classification algorithm, focusing here on the coordinates of the first two axes of the MFA, is a nonhierarchical classification which makes it possible to reveal a group structure from a set of data thanks to an algorithm for partitioning data based on moving averages. It is used for corroborating the sets of the MFA graph.

The two-way clustering (TWC), which is a hierarchical aggregative and polythetic method of digital classification based-here-on the Euclidian distance and Ward's centroid grouping method, is applied to the vegetation data (McCune and Grace [19]). This method has the advantage of presenting, 
TABLE 2: The four natural regions studied (age, stratigraphy, and nature of the deposits).

\begin{tabular}{|c|c|c|c|c|c|}
\hline & System & Stage & $\begin{array}{l}\text { Nature of } \\
\text { deposits }\end{array}$ & Natural region & Sites \\
\hline \multirow{2}{*}{$\begin{array}{l}\text { Geology } 1 \\
\text { (primary) }\end{array}$} & Cambrian & $\begin{array}{l}\text { Revinian } \\
\text { Devillian }\end{array}$ & $\begin{array}{l}\text { Quartzites } \\
\text { Quartzphyllite }\end{array}$ & \multirow{2}{*}{ Arden } & \multirow{2}{*}{$26-27,30-32,36$} \\
\hline & Ordovician & Salmian & Phyllite & & \\
\hline $\begin{array}{l}\text { Geology } 2 \\
\text { (primary) }\end{array}$ & Eodevonian & Gedinian & $\begin{array}{l}\text { Quartzites } \\
\text { Phyllite } \\
\text { Shale } \\
\text { Sandstone } \\
\text { puddingstone } \\
\text { Arkose }\end{array}$ & Arden & $22,8,33,35,37-38$ \\
\hline $\begin{array}{l}\text { Geology } 3 \\
\text { (primary) }\end{array}$ & Eodevonian & $\begin{array}{l}\text { Siegenian } \\
\text { (Coblencian) }\end{array}$ & $\begin{array}{l}\text { Quartzphyllite } \\
\text { Phyllite } \\
\text { Psammites } \\
\text { Sandstone }\end{array}$ & Arden & $29,39-50$ \\
\hline $\begin{array}{l}\text { Geology } 4 \\
\text { (primary) }\end{array}$ & Eodevonian & $\begin{array}{l}\text { Emsian } \\
\text { (lower and } \\
\text { upper) }\end{array}$ & $\begin{array}{l}\text { Quartzite } \\
\text { Shale } \\
\text { Sandstone }\end{array}$ & Arden & 34 \\
\hline \multirow[t]{2}{*}{$\begin{array}{l}\text { Geology } 5 \\
\text { (primary) }\end{array}$} & Devonian & $\begin{array}{l}\text { Frasnian } \\
\text { Givetian } \\
\text { Famennian }\end{array}$ & $\begin{array}{l}\text { Nodular shale } \\
\text { Psammites } \\
\text { Limestone }\end{array}$ & \multirow[t]{2}{*}{$\begin{array}{l}\text { Famenne and } \\
\text { Condroz }\end{array}$} & \multirow[t]{2}{*}{$1-12,20,23-25$} \\
\hline & Carboniferous & $\begin{array}{l}\text { Tournaisian } \\
\text { Visean }\end{array}$ & $\begin{array}{l}\text { Macigno } \\
\text { Limestone }\end{array}$ & & \\
\hline \multirow[t]{2}{*}{$\begin{array}{l}\text { Geology } 6 \\
\text { (primary) }\end{array}$} & Jurassic & $\begin{array}{l}\text { Virtonian } \\
\text { Sinemurian } \\
\text { Toarcian } \\
\text { Bajocian }\end{array}$ & $\begin{array}{l}\text { Sand } \\
\text { Sandy limestone } \\
\text { Marl } \\
\text { Limestone }\end{array}$ & \multirow[t]{2}{*}{ Lorraine } & \multirow[t]{2}{*}{$13-19,21$} \\
\hline & Triassic & $\begin{array}{l}\text { Keuperian } \\
\text { Hettangian }\end{array}$ & Marl & & \\
\hline
\end{tabular}

TABLE 3: Medians of physicochemical parameters of the site clusters defined by the multiple factorial analysis (Cl1: Condroz and Famenne and $\mathrm{Cl} 2$ : Lorraine, $\mathrm{Cl} 3$ to 6: Arden) and prevailing geology.

\begin{tabular}{lcccccccccc}
\hline $\begin{array}{l}\text { Cluster } \\
(\mathrm{MFA})\end{array}$ & $\begin{array}{c}\mathrm{NH}_{4}{ }^{+} \\
(\mathrm{mgN} / \mathrm{l})\end{array}$ & $\begin{array}{c}\mathrm{Ca}^{2+} \\
(\mathrm{mg} / \mathrm{l})\end{array}$ & $\begin{array}{c}\text { Conductivity } \\
(\mu \mathrm{S} / \mathrm{cm})\end{array}$ & $\begin{array}{c}\mathrm{Mg}^{2+} \\
(\mathrm{mg} / \mathrm{l})\end{array}$ & $\begin{array}{c}\mathrm{NO}_{3}{ }^{-} \\
(\mathrm{mgN} / \mathrm{l})\end{array}$ & $\begin{array}{c}\mathrm{NO}_{2}{ }^{-} \\
(\mathrm{mgN} / \mathrm{l})\end{array}$ & $\begin{array}{c}\mathrm{PO}_{4}{ }^{3-} \\
(\mathrm{mgP} / \mathrm{l})\end{array}$ & $\begin{array}{c}\text { pH } \\
\text { alkalinity } \\
\left({ }^{\circ} \mathrm{Fr}\right)\end{array}$ & $\begin{array}{c}\text { Prevailing } \\
\text { geology }\end{array}$ \\
\hline $\mathrm{Cl} 1$ & 0.037 & 35.1 & 254 & 5.3 & 2.626 & 0.012 & 0.040 & 7.75 & 8.50 & $\mathrm{Geology} 5$ \\
$\mathrm{Cl} 2$ & 0.021 & 79.1 & 394 & 2.7 & 1.930 & 0.010 & 0.010 & 8.19 & 17.73 & $\mathrm{Geology} 6$ \\
$\mathrm{Cl} 3$ & 0.024 & 2.9 & 60 & 1.4 & 0.380 & 0.010 & 0.008 & 6.06 & 0.46 & $\mathrm{Geology} 1$ \\
$\mathrm{Cl} 4$ & 0.020 & 7.5 & 88 & 3.0 & 2.609 & 0.010 & 0.016 & 7.38 & 1.95 & $\mathrm{Geology} 3$ \\
$\mathrm{Cl} 5$ & 0.026 & 10.5 & 139 & 3.1 & 2.250 & 0.010 & 0.024 & 7.60 & 2.19 & Geology 2 \\
$\mathrm{Cl} 6$ & 0.017 & 4.2 & 57 & 2.1 & 0.976 & 0.010 & 0.005 & 7.23 & 0.75 & $\mathrm{Geology} 3$ \\
\hline
\end{tabular}

in a single figure, the sites, the entire set of taxa and their abundance. The dendrograms result from a first grouping on the rows (sites) and a second grouping on the columns (species) of the matrix.

The indicator species method makes it possible to identify the characteristic taxa of preestablished groups-here, groups of sites obtained by the two-way clustering (Dufrêne and Legendre [28]). By definition, in order to be considered as characteristic, a species must have an indicator species value (i.e., the product of the specificity and the reliability of the species in the group determined by the classification) equal or superior to $25 \%$. That is to say, the species must have an average abundance of $50 \%$ in the sites of a peculiar group compared to all the groups (specificity). Furthermore, it must be present in more than $50 \%$ of the sites of this group (fidelity). The use of the indicator species allows for the definition of the characteristic species of each group generated by the clustering.

The Mann-Whitney (or Mann-Whitney-Wilcoxon) test is a nonparametric test applied to verify if coverage of the phanerogams differs from one TWC cluster to another.

A canonical correspondence analysis (CCA), constraining the ordination of the species matrix by a multiple linear regression of environmental variables (Ter Braak [29], McCune and Grace [19]), is used for a global analysis of the 
available data. It is more adapted to the long gradients-a condition verified here-than the redundancy analysis.

The Monte Carlo test is a significance test and is here applied to the maximum indicator species for each species based on randomizations. The probability value $(p)$ is based on the proportion of the random grouping of species equal to or exceeding the observed value of the indicator species [19].

The computations were made with PCORD 6 for the twoway clustering [30], canonical correspondence analysis and the indicator species analysis, and XLSTAT 2011 [31] for the multiple factorial analysis.

\section{Results}

3.1. Characterization of the Sites. The multiple factorial analysis (Figure 2), corroborated by the result of a $k$-means classification applied to the coordinates of the sites in the first factorial plan of the MFA, separates the watercourses of the Arden (red triangles, geology 1 to 4), those of Lorraine (violet triangles, geology 6: Jurassic and Triassic systems) and those of Condroz and Famenne (green triangles, geology 5: Devonian and Carboniferous systems). The values of the physicochemical parameters relative to mineralization and the trophic level and the prevailing geology are given in Table 3. The site clusters are described hereafter in the order of this table.

In Condroz and Famenne, the watercourses of MFA cluster 1 (altitude sites: 100-199 m) flow on a schist and boulders substrate in a landscape of meadows or else a mosaic of meadows and deciduous forests. In Lorraine, the substrate is composed of sand and boulders, and the brooks of MFA cluster 2 (altitude sites: 200-299 m) flow into deciduous forests.

Parts of the Arden sites linked to geologies 2, 3, and 4 are densely grouped. A second MFA (Figure 3), restricted to the Arden sites, corroborated by a $k$-means classification, was carried out in order to analyse them more easily. Four clusters (MFA clusters 3 to 6) are highlighted by this analysis. Low and medium altitude sites (100-299 m), the violet triangles, include watercourses with a medium slope (0.5-7.5\%), flowing into meadows and deciduous forests, as well as mixed deciduous forests. The substrate is composed of boulders (geology 2).

Medium-to-high altitude sites (200-399 m), the green triangles, have higher altitude springs (400-499 m), different widths (from small brooks to rivers), and a medium or a strong slope (0.5-20\%), flowing into a landscape of deciduous or mixed forests. The substrate is composed of boulders (geologies 3 and 4).

Sites of high altitude (300-399 m), with extremely high springs $(\geq 500 \mathrm{~m})$, and an extremely strong slope $(>20 \%)$ are represented by red triangles. The landscape is composed of coniferous forests and a substrate of bedrock (geology $1)$.

Extremely high altitude sites $(\geq 500 \mathrm{~m})$, the black triangles, are characterized by a substrate of boulders (geology 3 ). These brooks flow into the centres of bogs or meadows and coniferous forests.
3.2. Characterization of the Vegetation. The observed macrophytic taxa include 12 species of phanerogams, 16 species of mosses and five species of liverworts, eight species and four genera of macroalgae, and one species of lichen.

3.2.1. Two-Way Clustering and Indicator Species Analysis. The results of the two-way clustering based on Euclidian distance and Ward's centroid method are shown in Figure 4. The characteristic species, established by the indicator species, which are at the same time the dominant and the constant species, are outlined in colour. They provide the best highlight of the floristic pattern of the natural regions. The values of this indicator are given in Table 4.

The cut level of the dendrogram has been determined thanks to the probability of the Monte Carlo randomization test of the indicator species at every level of the grouping [19]. The number of clusters which minimizes this is six (Figure 4(a)). The two-way clustering gathers the species into six main groups (Figure 4(b): Gr1 to Gr6) and the sites into six clusters (Figure 4(b): sites 1 to 12,13 to 20,21 to 25,26 to 32, 33 to 44 and 45 to 50 , resp.).

Some species from groups 1 to 5 determined the two first site clusters, corresponding to small brooks, brooks, and rivers. The first TWC cluster includes sites from Condroz and Famenne (sites 1 to 12, in magenta red in Figure 4(b)). The abundances of the characteristic species of this cluster (Hygroamblystegium tenax, Cratoneuron filicinum, Leptodictyum riparium) are outlined in magenta red in Figure 4(b). The second TWC cluster comprises sites from the Lorraine region (sites 13 to 19, in green in Figure 5) and Condroz (site 20), characterized by Berula erecta, Cratoneuron filicinum, Nasturtium officinalis, Palustriella commutata, and Pellia endiviifolia (abundance outlined in green in Figure 4(b)). The third TWC cluster includes only sites from large rivers (sites 21 to 25) independently of the natural region (Figure 5) and is characterized by the species outlined in red in Figure 4(b): Cladophora glomerata, Hildenbrandia rivularis, Lemanea fluviatilis, Myriophyllum spicatum, Paralemanea catenata, Potamogeton crispus, Ranunculus fluitans and Stigeoclonium tenue. The fourth TWC cluster comprises the sites (26 to 32) of small brooks from the north-east, the central, and the north-west Arden region, characterized by the species outlined in dark blue in Figure 4(b): Hyocomium armoricum, Marsupella emarginata, Microspora tumidula, Mougeotia sp., Nardia compressa, Racomitrium aciculare, R. aquaticum, and Scapania undulata. No phanerogam occurs here. The fifth TWC cluster includes the sites (33 to 44) of the watercourses of various widths from Arden characterized by the species outlined in black (exclusively some bryophytes): Chiloscyphus polyanthos, Fontinalis squamosa, Hygroamblystegium fluviatile, and Platyhypnidium riparoides. The last TWC cluster comprises sites from south and north-east Arden (sites 45 to 50), characterized by the species outlined in light blue in Figure 4(b): Callitriche hamulata, Fontinalis antipyretica, Myriophyllum alterniflorum, and Ranunculus penicillatus.

From the two-way clustering in Figure 4(b), it emerges that the watercourses of the Condroz, Famenne and Lorraine regions have a core of species in common (Cratoneuron filicinum, Hygroamblystegium tenax, Pellia endiviifolia, and 


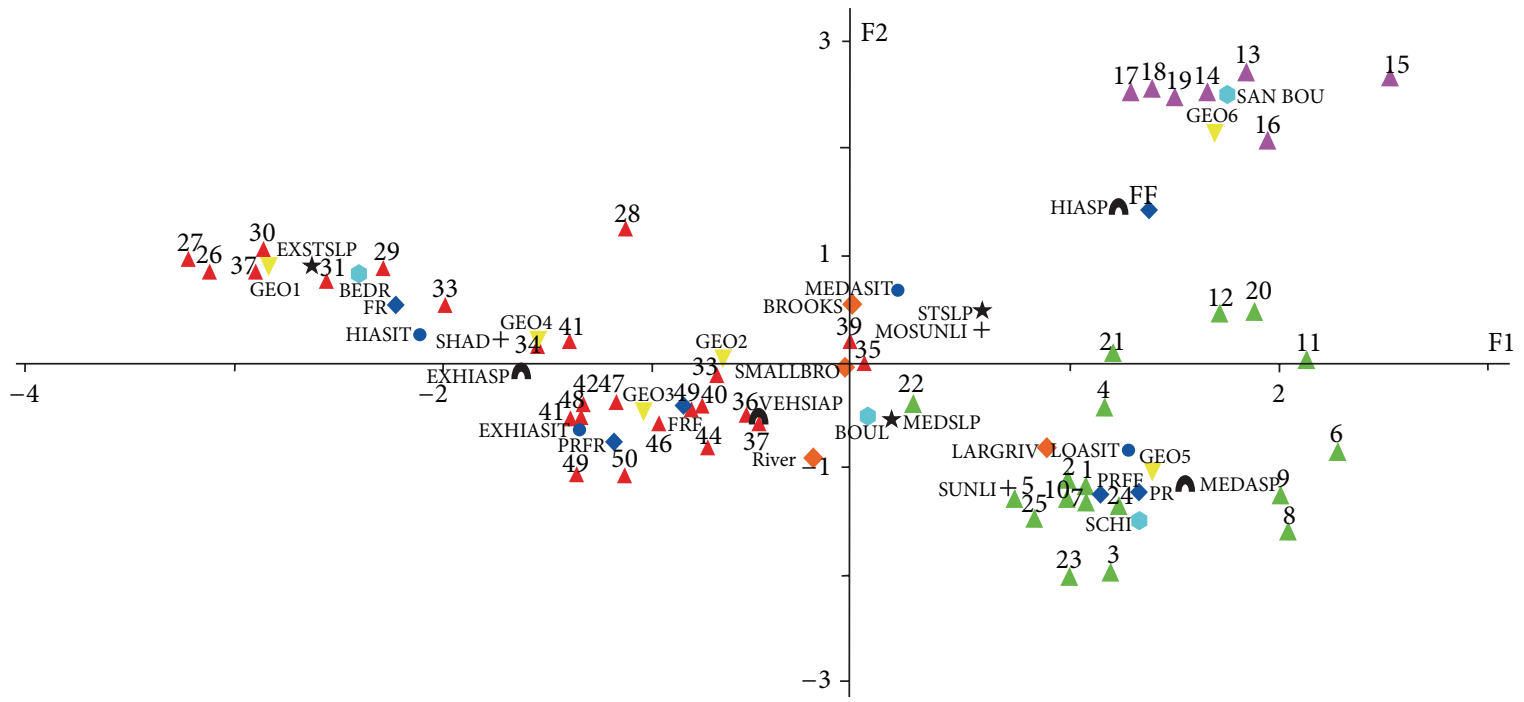
$\Delta$ Ardenne
A Famenne + Condroz
+ Shading
$\Delta$ Lorraine
- Site altitude
A Spring altitude

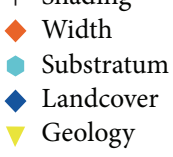
$\star$ Slope

FIgURE 2: MFA ordination of all sites. Plot of the sites and their parameters on the two first axes (\% variance axis $1=21.3$, axis $2=13.3$ ). Abbreviations: LOASIT: low altitude site, MEASIT: medium altitude site, HIASIT: high altitude site, EXHIASIT: extremely high altitude site, MEASP: medium altitude spring, HIASP: high altitude spring, VEHIASP: very high altitude spring, EXHIASP: extremely high altitude spring, MESLP: medium slope, STSLP: strong slope, EXSTSLP: extremely strong slope, SHAD: shady, MOSUNLIT: moderately sunlit, SUNLIT: sunlit, FF: deciduous forest, FR: conifer forest, FRF: deciduous and conifer forest, PRFR: meadow and conifer forest, PRFF: meadow and deciduous forest, PR: meadow, SCHI: shale, SAND BOUL: sand and boulder, BOUL: boulder, BEDR: bedrock, and SMALLBRO: small brooks. GEO1: Revinian, Devillian, and Salmian. GEO2: Gedinian. GEO3: Siegenian (Coblencian). GEO4: Emsian (lower and upper). GEO5: Frasnian, Givetian, Famennian, Tournaisian, and Visean. GEO6: Virtonian, Sinemurian, Toarcian, Bajocian, Keuperian, and Hettangian (details in Table 2).

Cladophora glomerata) and possess species that are more directly linked to those natural regions, such as Hygroamblystegium tenax, on one hand, and Pellia endiviifolia, on the other. The most ubiquitous species are outlined in yellow: the moss Brachytecium rivulare and the macroalgae of the genus Vaucheria.

The clustering of the small brooks, brooks and rivers in clusters 1,2, 5, and 6 indicates that the flora does not change with the width of watercourses in the Condroz, Arden and Lorraine areas.

The association of the large rivers in the third cluster indicates that the flora of the large rivers considered are similar but different from the other watercourses.

3.2.2. Canonical Correspondence Analysis. The results of CCA applied to characteristic species and variables of the environment are given in Figures 6 and 7. The results of CCA for the sites show that TWC clusters 1 and 2 are linked to geologies 5 and 6 (Famenne, Condroz, and Lorraine) and constitute a group of calcareous watercourses. In contrast, TWC clusters 4 to 6 are related to geologies 3 and 1 (Arden) and correspond to siliceous watercourses. The TWC third cluster is more closely linked to the width of the watercourse than any particular geology.
The results of CCA for the species show that geology 1 , with an extremely strong slope and raw substrate (bedrock), determines the presence of Hyocomium armoricum, Marsupella emarginata, Microspora tumidula, Mougeotia sp., Nardia compressa, Racomitrium aquaticum, R. aciculare, and Scapania undulata. These species, characteristic of the TWC fourth cluster, are linked to low $\mathrm{pH}$, conductivity, alkalinity, and calcium. Callitriche hamulata, Fontinalis squamosa, Myriophyllum alterniflorum, and Ranunculus penicillatuscharacteristic of the TWC sixth cluster-are related to geology 3 (Siegenian) and low slope, but also to low conductivity, alkalinity, and calcium. Hygroamblystegium tenaxcharacteristic of the first cluster-is found in geologies 5 and 6. Berula erecta, Cratoneuron filicinum, Nasturtium officinale, Palustriella commutata, and Pellia endiviifolia-characteristic of TWC cluster 2-are linked to geology 6 . All these species prefer high values of calcium, alkalinity, and conductivity.

Hildenbrandia rivularis, Lemanea fluviatilis, Myriophyllum spicatum, Paralemanea catenata, Potamogeton crispus, Ranunculus fluitans, and Stigeoclonium tenue, characteristic of the TWC third cluster, are related to great width (large rivers).

TWC clusters 4, 5, and 6 differ from each other by a statistically significant increased average of the coverage of 


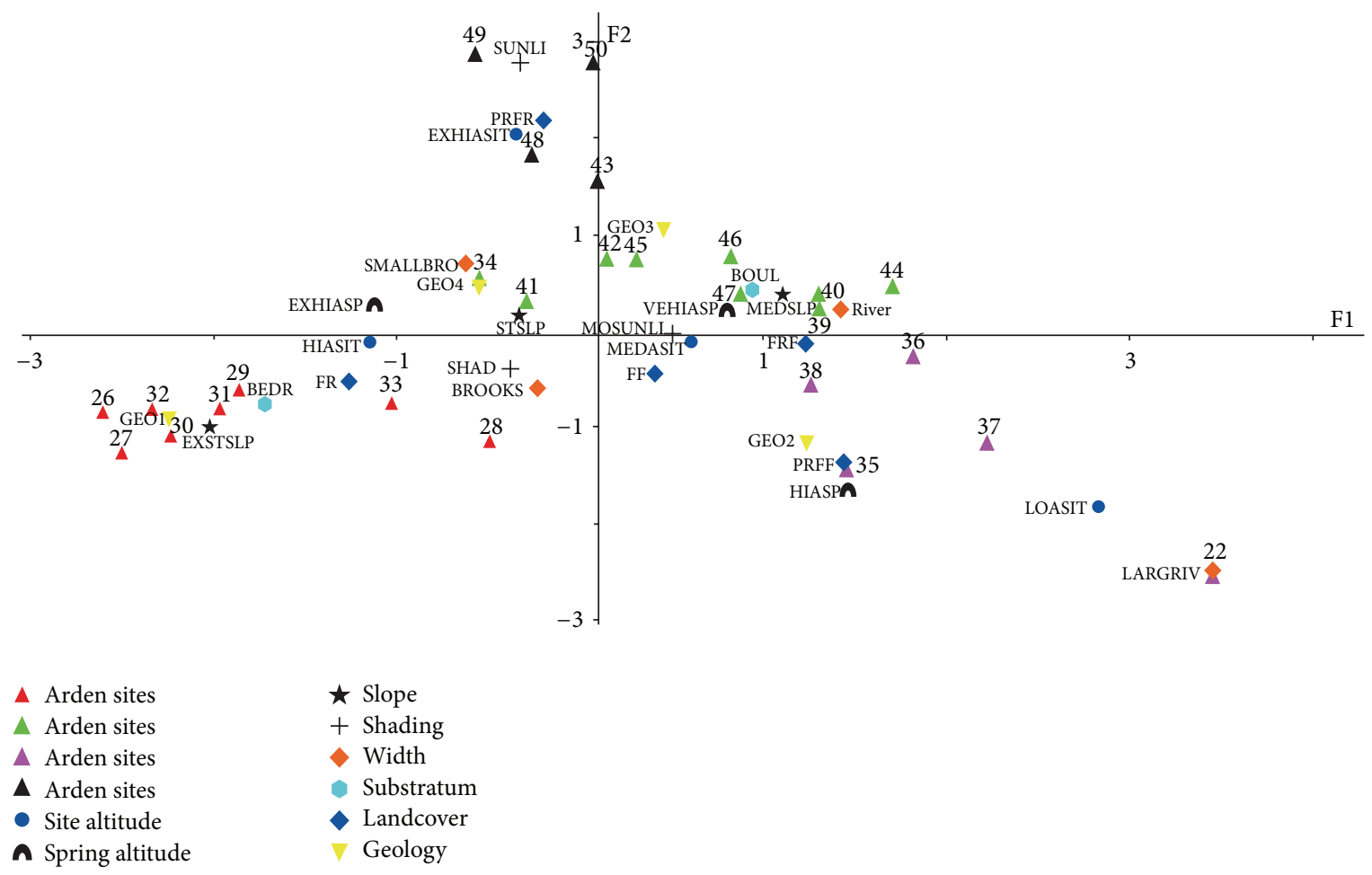

Figure 3: MFA ordination of the Arden sites. Plot of the sites and their parameters on the two first axes (\% variance axis $1=23.9$, axis 2 = 15.2). Abbreviations: LOASIT: low altitude site, HIASIT: high altitude site, EXHIASIT: extremely high altitude site, HIASP: high altitude spring, VEHIASP: very high altitude spring, EXHIASP: extremely high altitude spring, MESLP: medium slope, STSLP: strong slope, EXSTSLP: extremely strong slope, SHAD: shady, MOSUNLIT: moderately sunlit, SUNLIT: sunlit, FF: deciduous forest, FR: conifer forest, FRF: deciduous and conifer forest, PRFR: meadow and conifer forest, BOUL: boulder, BEDR: bedrock, and SMALLBRO: small brooks.

the phanerogams (Mann-Whitney test, $P<0.001$ ). This increase in the representation of phanerogams seems to be linked to a lower slope, to more intense illumination, and to the nature of the geological substrate-the Siegeniancreating waters that are richer in mineral elements than the Revinian, the Devillian, the Silurian, and the Gedinian [32].

\section{Discussion}

Both the MFA and the TWC result in defining six clusters of sites. These clusters coincide in $78 \%$ of the cases. Large streams are characterized more by their flora than by environmental parameters and are therefore not highlighted as a cluster in the MFA. Because of their physicochemical and environmental characteristics, cluster 3 sites of the TWC merge into the Condroz and Famenne cluster of the MFA. In cluster 6 of the TWC (including six streams), four streams also constitute a group in the MFA. All these elements clearly show how closely floristically these groups are linked to the natural regions.

The Sossey-Alaoui and Rosillon work [14] around diversely impacted watercourses inside the monitoring network of the Walloon Region had highlighted six "groups" relatively different from our clusters. In both analyses, the large rivers group and the group of Belgian Lorraine (nonimpacted watercourses) stand out clearly and are similar, but the others differ. A strongly eutrophized watercourses group with its specific floristic composition has been established by SosseyAlaoui and Rosillon [op. cit.], mostly in the Limoneuse region. In contrast, in the other groups of this study, the impact of the natural region on the flora seems hidden by the eutrophization. Characteristic species of the eutrophization, especially macroalgae, are indeed common in five natural regions (Ardennes, the Limoneuse Region, Condroz, Famenne, Lorraine). The low impacted watercourses group of Sossey-Alaoui and Rosillon seems to be linked to Arden, but in a much less obvious way than in the set of data of the reference watercourses.

This demonstrates the need for a study based on reference watercourses exclusively.

The similarities in the macrophytic communities of the three natural regions with a limestone subsoil (Condroz, Famenne, and Lorraine) corroborate the results of previous works (Dethioux [33] and Symoens [34]).

This phenomenon could be explained by the quite similar physicochemical characteristics of the waters of these three natural regions - and in particular, the high level of calcium and alkalinity.

Our dataset (50 sites) concerns a small area $\left(12,000 \mathrm{~km}^{2}\right)$ and is the result of a high sampling fraction, which makes our study very representative of the study area. A German study [17] is based on 19 reference sites and a Polish one includes 40 sites [18]; a European study has 64 sites [35]. The Danish work deals with 43 sites widespread in Denmark and 


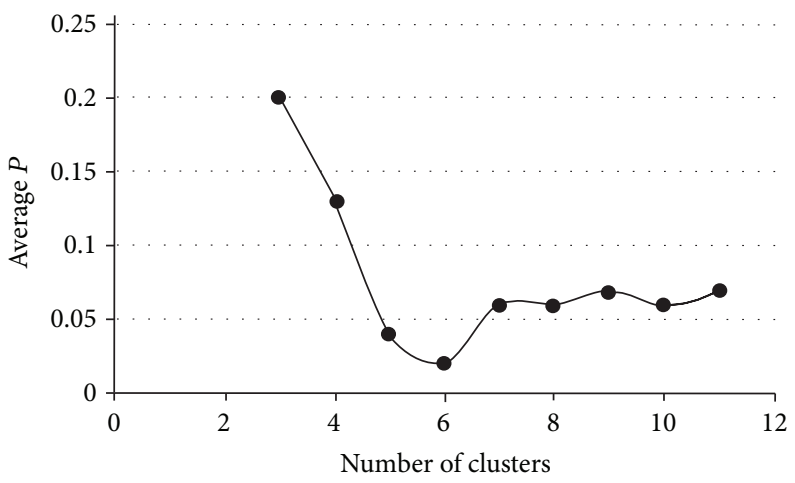

(a)

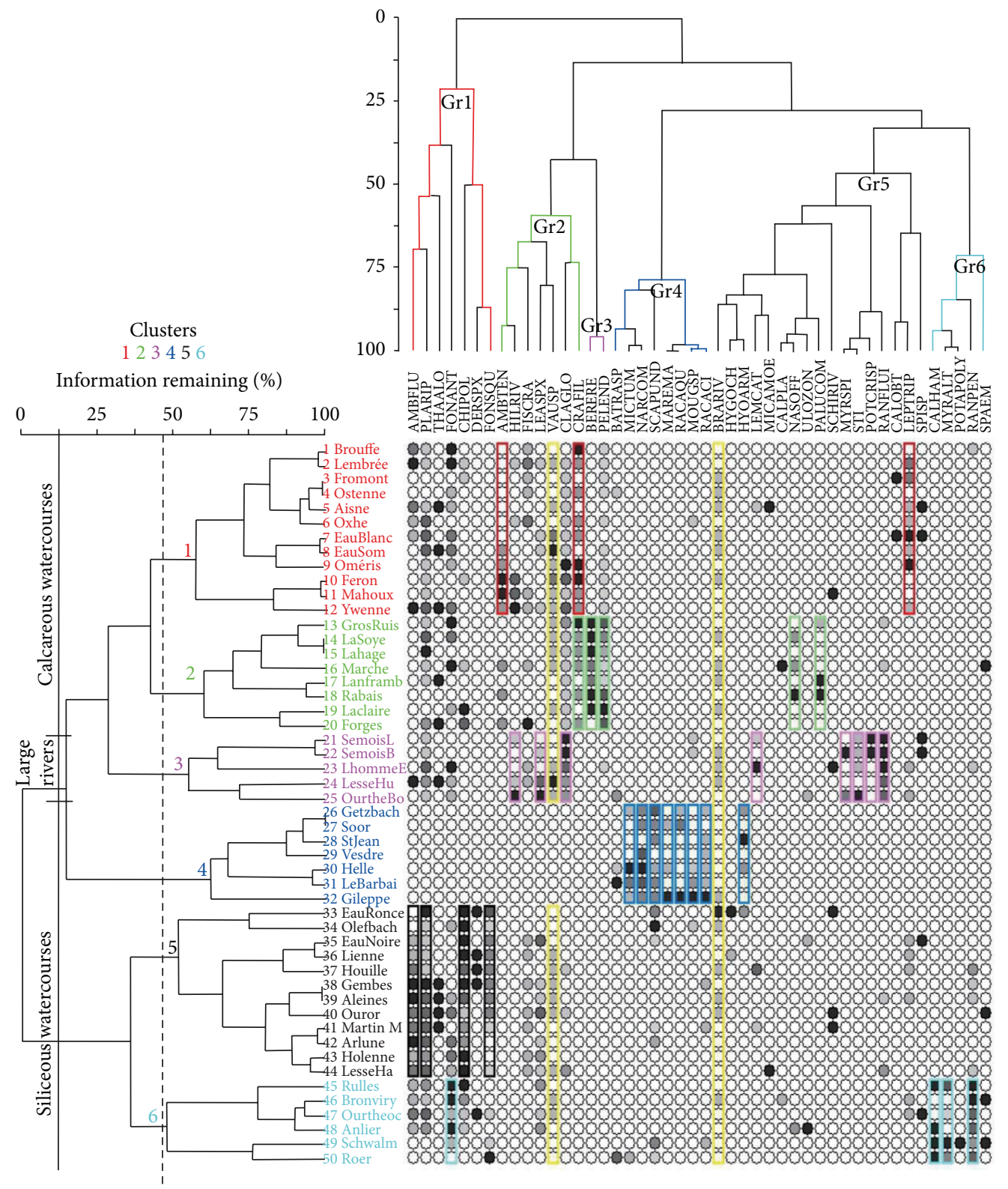

(b)

Figure 4: Probability of the Monte Carlo randomization test of the indicator species at every level of the grouping (a) and Two-way clustering of sites and species (b). The circles' colour intensities reflect the abundance of each species-the most ubiquitous species are outlined in yellow while the characteristic species are outlined with different colours. Abbreviations and full names are given at the end of the text. 
TABLE 4: Values of the indicator species calculated for each one of six clusters. The values $\geq 25 \%$ are in bold.

\begin{tabular}{|c|c|c|c|c|c|c|c|c|c|c|c|c|c|}
\hline \multirow{2}{*}{ Taxa } & \multicolumn{6}{|c|}{ Clusters } & \multirow{2}{*}{ Taxa } & \multicolumn{6}{|c|}{ Clusters } \\
\hline & 1 & 2 & 3 & 4 & 5 & 6 & & 1 & 2 & 3 & 4 & 5 & 6 \\
\hline Hygroamblystegium fluviatile & 12 & 0 & 3 & 0 & 34 & 14 & Microspora tumidila & 0 & 0 & 0 & 49 & 0 & 2 \\
\hline Hygroamblystegium tenax & 25 & 15 & 0 & 0 & 0 & 0 & Mougeotia sp. & 0 & 0 & 10 & 27 & 0 & 0 \\
\hline Batrachospermum sp. & 0 & 0 & 5 & 12 & 0 & 5 & Myriophyllum alterniflorum & 0 & 0 & 0 & 0 & 0 & 67 \\
\hline Berula erecta & 0 & 88 & 0 & 0 & 0 & 0 & Myriophyllum spicatum & 0 & 0 & 40 & 0 & 0 & 0 \\
\hline Brachytecium rivulare & 10 & 10 & 14 & 1 & 10 & 1 & Nardia compressa & 0 & 0 & 0 & 86 & 0 & 0 \\
\hline Callitriche hamulata & 0 & 0 & 0 & 0 & 0 & 67 & Nasturtium officinale & 0 & 28 & 0 & 0 & 0 & 4 \\
\hline Callitriche obtusangula & 17 & 0 & 0 & 0 & 0 & 0 & Palustriella commutata & 0 & 38 & 0 & 0 & 0 & 0 \\
\hline Callitriche platycarpa & 0 & 9 & 0 & 0 & 0 & 5 & Pellia endiviifolia & 17 & 74 & 1 & 0 & 0 & 0 \\
\hline Chiloscyphus polyanthos & 1 & 6 & 0 & 0 & 56 & 15 & Platyhypnidium riparoides & 15 & 13 & 19 & 0 & 29 & 11 \\
\hline Cladophora glomerata & 23 & 19 & 50 & 0 & 1 & 0 & Potamogeton crispus & 0 & 0 & 40 & 0 & 0 & 0 \\
\hline Cratoneuron filicinum & 40 & 35 & 0 & 0 & 0 & 0 & Potamogeton polygonifolius & 0 & 0 & 0 & 0 & 0 & 17 \\
\hline Dermatocarpon luridum & 0 & 0 & 0 & 0 & 22 & 6 & Racomitrium aciculare & 0 & 0 & 0 & 66 & 2 & 2 \\
\hline Fissidens crassipes & 20 & 6 & 7 & 0 & 15 & 0 & Racomitrium aquaticum & 0 & 0 & 0 & 43 & 0 & 0 \\
\hline Fontinalis antipyretica & 14 & 9 & 10 & 0 & 6 & 26 & Ranunculus fluitans & 0 & 2 & 88 & 0 & 1 & 0 \\
\hline Fontinalis squamosa & 0 & 0 & 0 & 0 & 53 & 18 & Ranunculus penicillatus & 0 & 0 & 1 & 0 & 4 & 82 \\
\hline Hildenbrandia rivularis & 19 & 0 & 33 & 0 & 0 & 0 & Scapania undulata & 0 & 0 & 0 & 52 & 10 & 5 \\
\hline Hygrohypnum ochraceum & 0 & 0 & 0 & 0 & 17 & 0 & Schistidium rivulare & 1 & 0 & 8 & 0 & 12 & 0 \\
\hline Hyocomium armoricum & 0 & 0 & 0 & 37 & 1 & 0 & Sparganium emersum & 0 & 3 & 0 & 0 & 1 & 21 \\
\hline Lemanea fluviatilis & 3 & 0 & 25 & 0 & 15 & 11 & Spirogyra sp. & 3 & 0 & 20 & 0 & 1 & 3 \\
\hline Paralemanea catenata & 0 & 0 & 28 & 0 & 4 & 0 & Stigeoclonium tenue & 0 & 0 & 80 & 0 & 0 & 0 \\
\hline Leptodictyum riparium & 35 & 0 & 7 & 0 & 5 & 5 & Thamnobryum alopecurum & 6 & 6 & 4 & 0 & 11 & 0 \\
\hline Marsupella emarginata & 0 & 0 & 0 & 43 & 0 & 0 & Ulothrix zonata & 0 & 0 & 5 & 0 & 1 & 11 \\
\hline Microspora amoena & 4 & 0 & 0 & 0 & 4 & 0 & Vaucheria sp. & 11 & 17 & 0 & 7 & 3 & 11 \\
\hline
\end{tabular}

surrounding countries [16]. It also points out the difficulty of finding reference sites.

The Polish work has threshold reference criteria similar to ours concerning land use except for urban use (1\% against $4 \%$ in Wallonia) but has less demanding values for the physicochemical parameters, which is normal because it dealt with the lowlands regions of Poland.

Germany is the only country that published a typology of reference watercourses, the neighbouring parts of which are comparable with our conditions.

For the selection of the reference sites, the German study refers to the European guidance work in a very general way. Our physicochemical reference criteria are in concordance with those of the Germans. The low values of orthophosphate and ammoniacal nitrogen of our selected sites must be underlined. Comparing with the German analysis, we can conclude that our clusters 4, 5, and 6 can be classified within the type MRS (fast flowing brooks and rivers of mountain areas, ecoregion 9 according to WFD, soft water, alkalinity $<1.4 \mathrm{mmole} / \mathrm{L})$. The vegetation is mainly made up of bryophytes (e.g., Chiloscyphus polyanthos) and phanerogams (Callitriche hamulata, Myriophyllum alterniflorum, and Potamogeton polygonifolius).

Our clusters 1 and 2 can be related to the type MRK (fast flowing brooks and rivers in mountainous areas, ecoregion 9 , hard water $>1.4 \mathrm{mmole} / \mathrm{L}$ ). Here, the vegetation is also dominated by bryophytes like Cinclidotus sp. and Cratoneuron filicinum.
Our cluster 3 can be assimilated to the type $\mathrm{MP}(\mathrm{G})$ (lowland rivers in mountainous areas, subtype MP). Charales, bryophytes, and phanerogams make up the floristic cortege.

The characteristic species (defined in Wallonia thanks to the indicator species analysis) do not always coincide with the German study because Germany does not include macroalgae in their analysis and they use three categories of taxa: (1) species abundant at reference sites and uncommon under non-reference sites (group A), (2) species rarely found under reference conditions and usually occurring at sites with very few or no group A taxa (group C), and (3) species showing no preference for reference or non-reference sites (group B). Our characteristic species belong to groups A and C.

\section{Conclusions}

Six clusters of watercourses were highlighted by the multiple factorial analysis of the physicochemical and environmental characteristics of the stations where the vegetation surveys were carried out.

The two-way clustering made it possible to identify six clusters of reference watercourses with different floristic compositions in the area south and east of the line between the Sambre and Meuse of the Walloon Region.

There is a close agreement between the results of both analyses.

The distribution of the sites according to their characteristic species shows a separation between the watercourses 


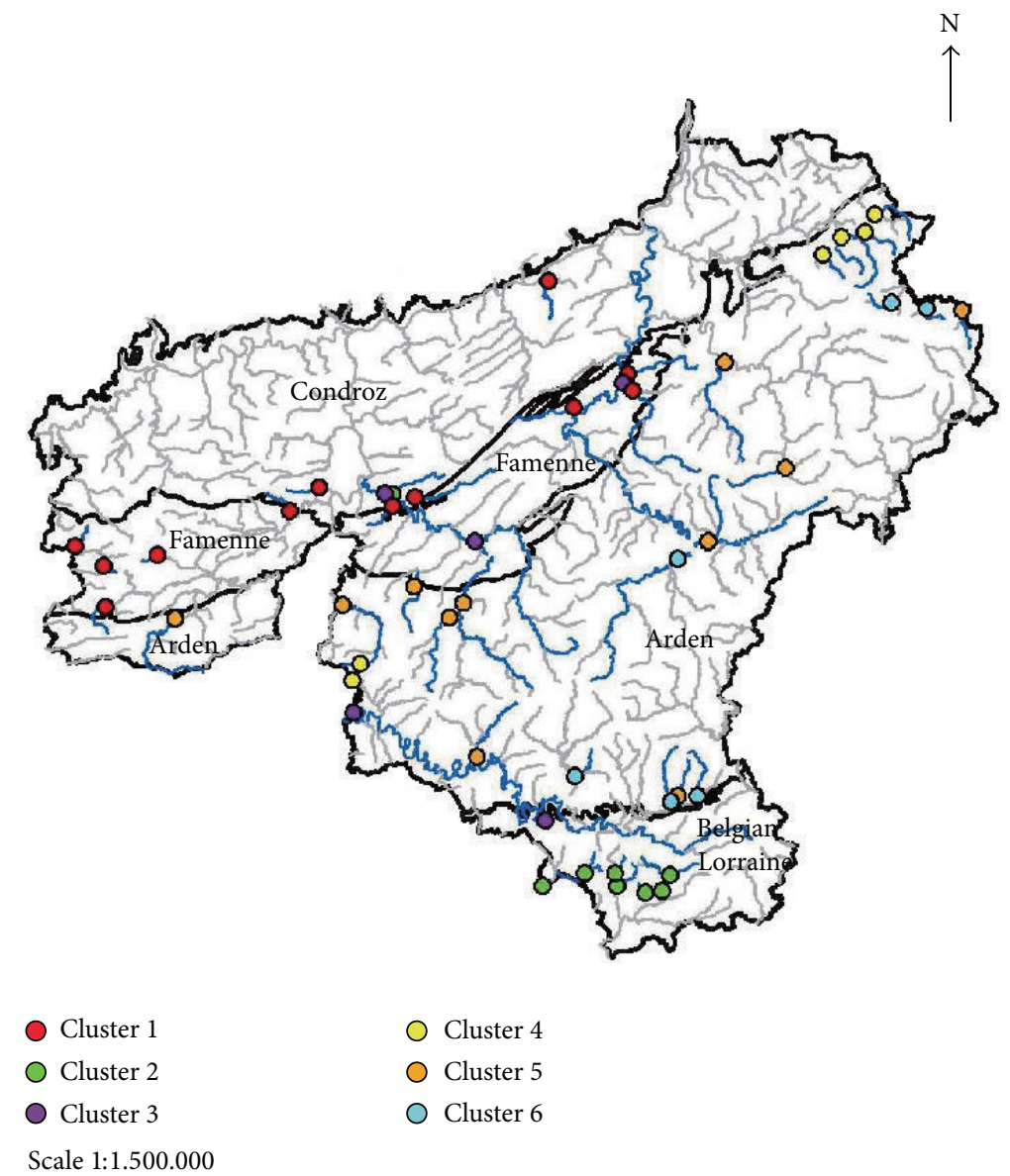

FIGURE 5: Distribution of the 50 studied sites in six clusters according to the results of two-way clustering analysis.

of the different natural regions (Condroz and Famenne, Belgian Lorraine, Arden) except for the large rivers (Semois, Lhomme, Ourthe, Lesse).

Our reference network can therefore be divided into calcareous and siliceous watercourses and large rivers.

In the Arden region, apart from the oligotrophic group of watercourses, it has been possible to define two groups, which are differentiated by the presence and cover of phanerogams. The abundance of phanerogams seems here to be linked to the lowest degree of slope (medium slope), more intense sunlight, and a geological substrate richer in mineral elements.

\section{Abbreviations}

AMBFLU: Hygroamblystegium fluviatile (Hedw.) Loeske

AMBTEN: Hygroamblystegium tenax (Hedw.) Jenn.

BATRACH: Batrachospermum Roth.

BERERE: Berula erecta (Huds.) Coville.

BRARIV: Brachythecium rivulare (Schimp.)

CALHAM: Callitriche hamulata (Kütz. ex Koch)

CALOBT: Callitriche obtusangula (Le Gall.)

CALPLA: Callitriche platycarpa (Kütz.)

CHIPOL: Chiloscyphus polyanthus (L.) Corda

CLAGLO: Cladophora glomerata (Linnaeus) Kützing
CRAFIL: Cratoneuron filicinum (Hedw.) Spruce.

DERPSPX: Dermatocarpon luridum (With.) J.R. Laundon

FISCRA: Fissidens crassipes (Wilson ex Bruch and Schimp.)

FONANT: Fontinalis antipyretica (Hedw.)

FONSQU: Fontinalis squamosa (Hedw.)

HILRIV: Hildenbrandia rivularis (Liebmann) J. Agardh.

HYGOCH: Hygrohypnum ochraceum (Turner ex Wilson) Loeske.

HYOARM: Hyocomium armoricum (Brid.) Wijk and Margad.

LEASPX: Lemanea fluviatilis (Linnaeus) C. Agardh LEMCAT: Paralemanea catenata (Kütz.) Vis and Sheath

LEPRIP: $\quad$ Leptodictyum riparium (Hedw.) Warnst

MAREMA: Marsupella emarginata (Ehrh.) Dumort.

MICTUM: Microspora tumidula Hazen

MOUGSP: Mougeotia. C. Agardh.

MYRALT: Myriophyllum alterniflorum DC

NARCOM: Nardia compressa (Hook.) S. Gray

NASOFF: $\quad$ Nasturtium officinale R. Brown

PALUCOM: Palustriella commutata (Hedw.) Ochyra

POTAPOLY: Potamogeton polygonifolius Pourr. 


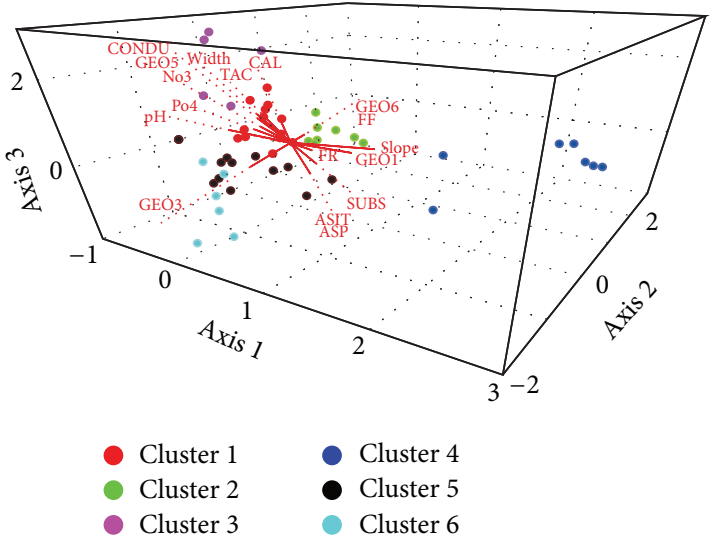

Figure 6: CCA ordination of the sites. Plots of the first, second, and third axes (\% variance axis $1=18.2$, axis $2=11.8$, and axis $3=10.2$ ). Only the variables having an $R^{2} \geq 0.30$ with the principal axes are plotted [19]. CONDU: conductivity, FR: conifer forest, FF: deciduous forest, ASIT: site altitude, ASP: spring altitude, SUBS: substrate, CAL: calcium, TAC: alkalinity, $\mathrm{pH}: \mathrm{pH}, \mathrm{NO}_{3}$ : nitrate nitrogen, $\mathrm{PO}_{4}$ : orthophosphates, and GEO 1, 3, 5, 6: geologies 1, 3, 5, 6 .

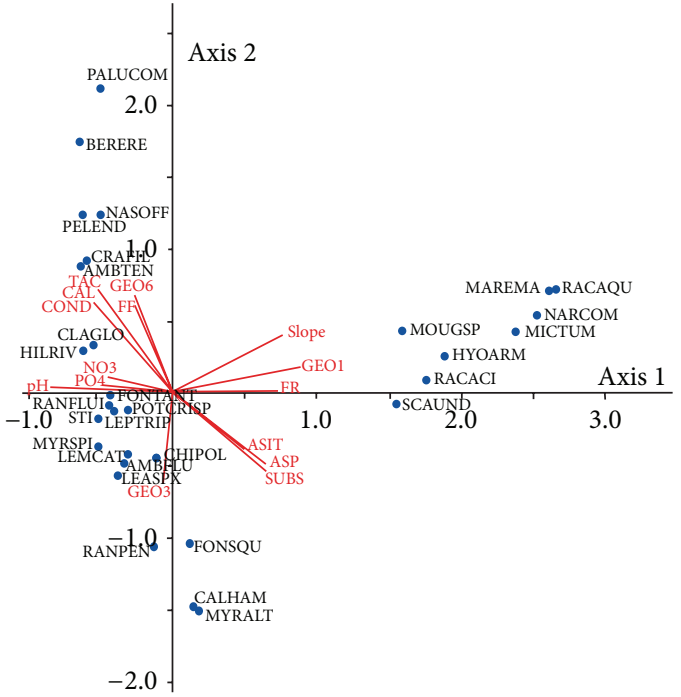

(a)

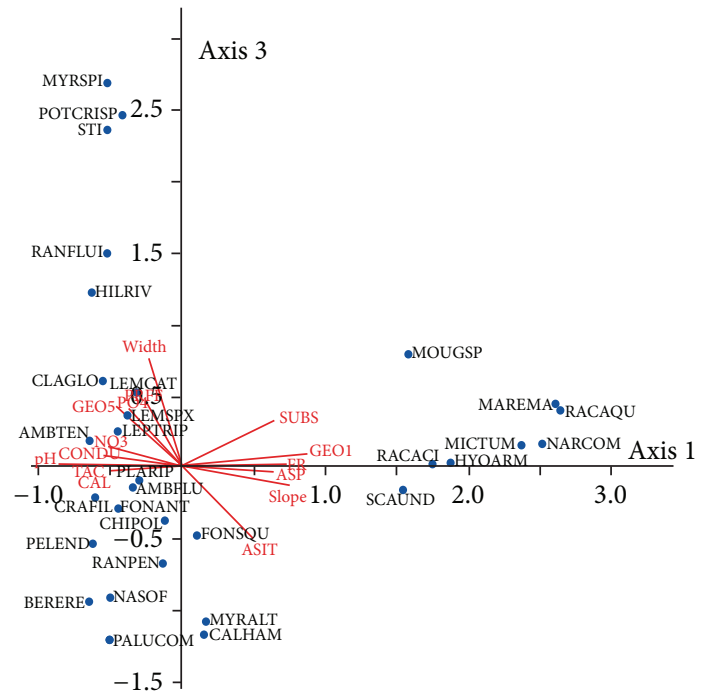

(b)

FIGURE 7: CCA ordination of the environmental variables and the characteristic species. Plots of the first, second (a), and third axes (b) (\% variance axis $1=18.2$, axis $2=11.8$, and axis $3=10.2$ ). Only the variables having an $R^{2} \geq 0.20$ with the principal axes are shown. CONDU: conductivity, PRFF: meadow and deciduous forest, PR: meadow, PRFR: meadow and conifer forest, PRFF: meadow and deciduous forest, FR: conifer forest, FF: deciduous forest, ASIT: site altitude, ASP: spring altitude, SUBS: substrate, CAL: calcium, TAC: alkalinity, $\mathrm{pH}$ : $\mathrm{pH}, \mathrm{NO}_{3}$ : nitrate nitrogen, $\mathrm{PO}_{4}$ : orthophosphates, GEO 1, 3, 5, 6: geologies 1, 3, 5, 6. Abbreviations and full names of the species are given in at the end of the text.

RACAC: Racomitrium aciculare (Hedw.) Brid

RACAQU: Racomitrium aquaticum (Brid. ex Schrad.) Brid.

RANFLU: Ranunculus fluitans Lam.

RANPEN: Ranunculus penicillatus (Dum.) Bab.

PLARIP: Platyhypnidium riparoides (Hedw.) Dixon

RICCHA: Riccardia chamedryfolia (With.) Grolle

SCAUND: Scapania undulata (L.) Dumort.

SCHIRIV: Schistidium rivulare (Brid.) Podp.

SPAEM: Sparganium emersum (Rehm.)

THAALO: Thamnobryum alopecurum (Hedw.) Gangulee.
ULOZON: Ulothrix zonata (F. Weber and D. Mohr) Kützing

VAUSP: Vaucheria de Candolle.

\section{Conflict of Interests}

The authors declare that there is no conflict of interests regarding the publication of this paper.

\section{Acknowledgment}

The authors would like to thank Jonathan Devriese (Département de l'Étude du Milieu Naturel et Agricole) for his technical assistance with the graphics. 


\section{References}

[1] A. Kohler, "Submerse Macrophyten and ihre Gesellschaften als Indikatoren der Gewasserbelastung," Beiträge zur Naturkundlichen Forschung in Südwestdeutschland, vol. 34, pp. 149-154, 1975.

[2] A. Kohler, "Wasserpflanzen als Bioindikatoren," DechenianaBeihefte, vol. 26, pp. 31-42, 1982.

[3] C. Newbold and N. T. H. Holmes, "Nature conservation: water quality criteria and plants as water quality monitors," Water Pollution Control, vol. 86, no. 2, pp. 345-364, 1987.

[4] S. M. Haslam, River Plants of Western Europe: The Macrophyte Vegetation of Water Courses of the European Community, Cambridge University, Cambridge, UK, 1987.

[5] J. Haury and M.-C. Peltre, "Intérêts et limites des indices macrophytiques pour qualifier la mésologie et la physicochimie des cours d'eau: exemples armoricains, picards, lorrains," Annales de Limnologie, vol. 29, no. 3-4, pp. 239-253, 1993.

[6] N. T. H. Holmes, J. R. Newman, S. Chadd, K. J. Rouen, L. Saint, and F. H. Dawson, "Mean trophic rank: a user's manual," R\&D Technical Report E38, Environment Agency, Bristol, UK, 1999.

[7] J. Haury, M.-C. Peltre, M. Trémolières et al., "A new method to assess water trophy and organic pollution-the Macrophyte Biological Index for Rivers (IBMR): its application to different types of river and pollution," Hydrobiologia, vol. 570, no. 1, pp. 153-158, 2006.

[8] S. Schneider and A. Melzer, "The Trophic Index of Macrophytes (TIM) - a new tool for indicating the trophic state of running waters," International Review of Hydrobiology, vol. 88, no. 1, pp. 49-67, 2003.

[9] R. W. Butcher, "Studies on the ecology of rivers: I. On the distribution of macrophytic vegetation in the rivers of Britain," The Journal of Ecology, vol. 21, no. 1, pp. 58-91, 1933.

[10] N. T. H. Holmes, P. J. Boon, and T. A. Rowell, "Revised classification for British rivers based on their plant communities," in Aquatic Conservation: Marine and Freshwater Ecosystems, vol. 8, pp. 555-578, 1998.

[11] N. Grasmück, J. Haury, L. Léglize, and S. Müller, "Analyse de la végétation aquatique fixée des cours d'eau lorrains en relation avec les paramètres de l'environnement," Annlales de Limnologie, vol. 29, no. 3-4, pp. 223-237, 1993.

[12] P. Chatenet, M. Botineau, J. Haury, and A. Ghestem, "Typologie de la végétation macrophytique des rivières et affluents de la vienne et de la Gartempe (Limousin, France)," Acta Botanica Gallica, vol. 147, no. 2, pp. 151-164, 2000.

[13] K. Sossey-Alaoui, Contribution méthodologique à l'évaluation de la qualité des eaux des rivières à l'aide des macrophytes aquatiques (Spermatophytes et Bryophytes)_Application au réseau hydrographique luxembourgeois [Thèse de Doctorat], Université de Liège, Liège, Belgium, 2005.

[14] K. Sossey-Alaoui and F. Rosillon, "Macrophytic distribution and trophic state of some natural and impacted watercoursesBelgium Wallonia," International Journal of Water Sciences, vol. 2, no. 2, pp. 1-11, 2013.

[15] European Union, "Directive 2000/60/EC of the European Parliament and of the council of 23 October 2000 establishing a framework for community action in the field of water policy," Official Journal of the European Communities L, vol. 327, p. 72, 2000.

[16] A. Baattrup-Pedersen, G. Springe, T. Riis, S. E. Larsen, K. Sand-Jensen, and L. M. Kjellerup Larsen, "The search for reference conditions for stream vegetation in northern Europe," Freshwater Biology, vol. 53, no. 9, pp. 1890-1901, 2008.

[17] P. Meilinger, S. Schneider, and A. Melzer, "The reference index method for the macrophyte-based assessment of rivers-a contribution to the implementation of the European Water Framework Directive in Germany," International Review of Hydrobiology, vol. 90, no. 3, pp. 322-342, 2005.

[18] K. Szoszkiewicz, S. Jusik, A. E. Lawniczak, and T. Zgola, "Macrophyte development in unimpacted lowland rivers in Poland," Hydrobiologia, vol. 656, no. 1, pp. 117-131, 2010.

[19] B. McCune and J. B. Grace, PCORD Analysis of Ecological Communities, MJM Software Design, Lincoln Beach, Ore, USA, 2002.

[20] European Commission Joint Research, "Common implementation strategy for the water framework directive (2000/60/CE), documents nos. $5 \& 10$ and water framework directive intercalibration technical report-rivers," Tech. Rep., Centre Institute for Environment and Sustainability, Ispra, Italy, 2000.

[21] Agence de l'Eau Rhin Meuse, Evaluation de la qualité du milieu physique des cours d'eau du bassin Rhin-Meuse. Catalogue des données recueillies de 1995 à 2001 et perspectives, Agence de l'Eau Rhin Meuse, 1995.

[22] J. Lambinon, L. Delvosalle, and J. Duvigneaud, Nouvelle flore de la Belgique, du Grand-Duché de Luxembourg, du Nord de la France et des régions voisines (Ptéridophytes et Spermatophytes), Jardin Botanique National de Belgique, Meise, Belgium, 6th edition, 2012.

[23] A. J. E. Smith, The Moss Flora of Britain and Ireland, Cambridge University Press, Cambridge, UK, 2nd edition, 2008.

[24] H. Siebel and H. During, Beknopte Mosflora van Nederland en België, KNVV Uitgeverij, Utrecht, The Netherlands, 2006.

[25] D. M. John, B. A. Whitton, and A. J. Brook, The Freshwater Algal Flora of the British Isles. An Identification Guide to Freshwater and Terrestrial Algae, Cambridge University Press, Cambridge, UK, 2011.

[26] Afnor, "Qualité de l'eau. Détermination de l'indice biologique macrophytique en rivière (IBMR)," Tech. Rep. norme T90-395, Association Française de Normalisation, Paris, France, 2003.

[27] B. Escoffier and J. Pages, Analyses Factorielles Simples et Multiples, Dunod, Paris, France, 1998.

[28] M. Dufrêne and P. Legendre, "Species assemblages and indicator species: the need for a flexible asymmetrical approach," Ecological Monographs, vol. 67, no. 3, pp. 345-366, 1997.

[29] C. J. F. Ter Braak, "Canonical correspondence analysis: a new eigenvector technique for multivariate direct gradient analysis," Ecology, vol. 67, no. 5, pp. 1167-1179, 1986.

[30] B. MacCune and M. J. Mefford, PC-ORD. Multivariate Analyse of Ecological Data. Version 6, MjM Software, Gleneden Beach, Ore, USA, 2011.

[31] XLSTAT, Analyse de données et modélisation avec Microsoft Excel, 2011, Addinsoft SARL. Version, http://www.xlstat.com.

[32] R. Fabri and L. Leclercq, "Végétation et caractéristiques physico-chimiques des eaux de trois rivières de haute Ardenne (Belgique): la Helle, la Roer et la Warche," Bulletin de la Société Royale de Botanique de Belgique, vol. 110, pp. 202-216, 1977.

[33] M. Dethioux, Les cours d'eau de Wallonie: Caractéristiques physiques et floristiques-Principes et techniques de verduration, Institut pour l'Encouragement de la Recherche Scientifique dans l'Industrie et l'Agriculture (I.R.S.I.A.), Brussels, Belgium, 1991. 
[34] J. P. Symoens, "Les eaux courantes de l'Ardenne et des régions voisines: Les milieux et leur végétation algale," Bulletin de la Société Royale de Botanique de Belgique, vol. 89, pp. 1-111, 1957.

[35] A. Baattrup-Pedersen, K. Szoszkiewicz, R. Nijboer, M. O’Hare, and T. Ferreira, "Macrophyte communities in unimpacted European streams: variability in assemblage patterns, abundance and diversity," Hydrobiologia, vol. 566, no. 1, pp. 179-196, 2006. 

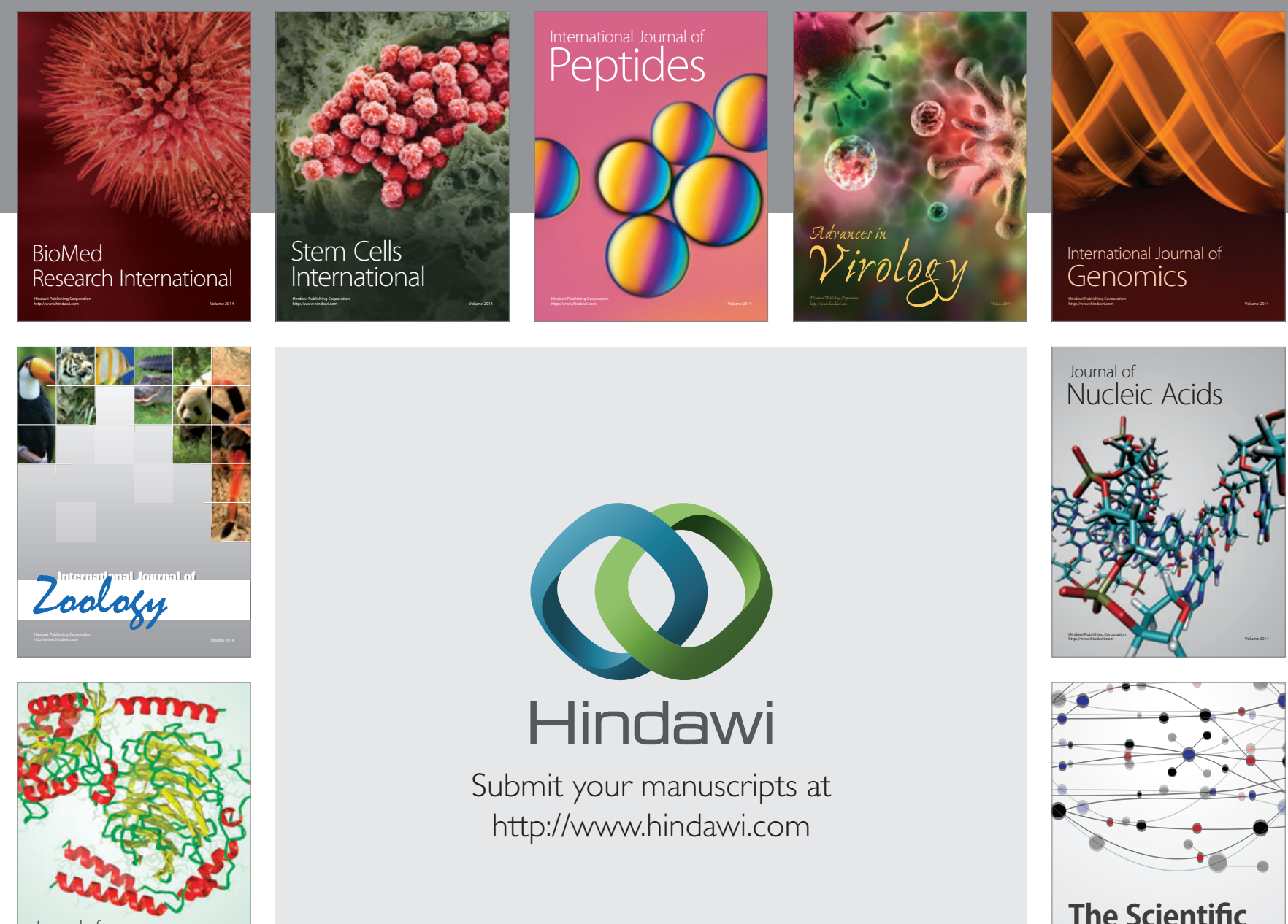

Submit your manuscripts at

http://www.hindawi.com

Journal of
Signal Transduction
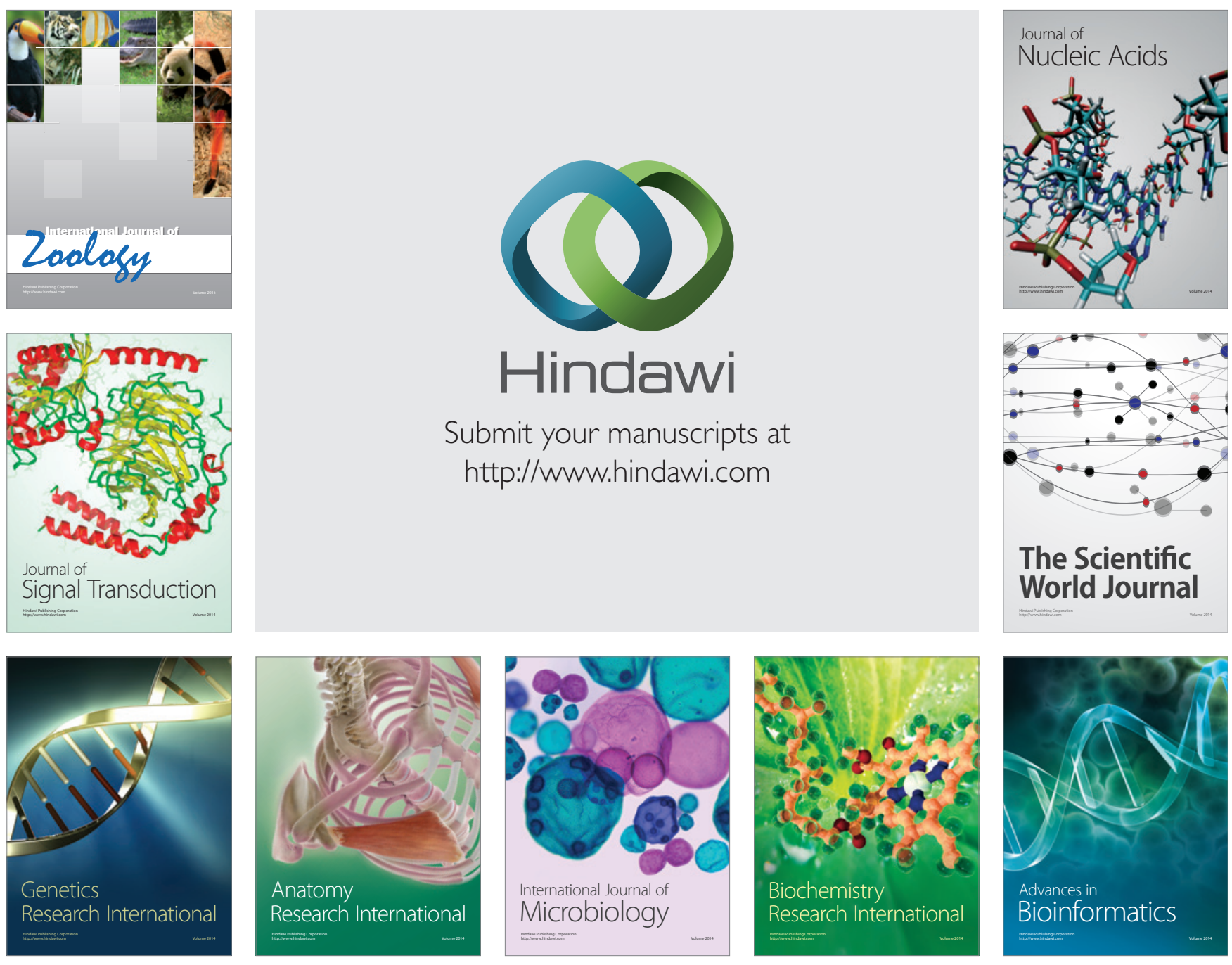

The Scientific World Journal
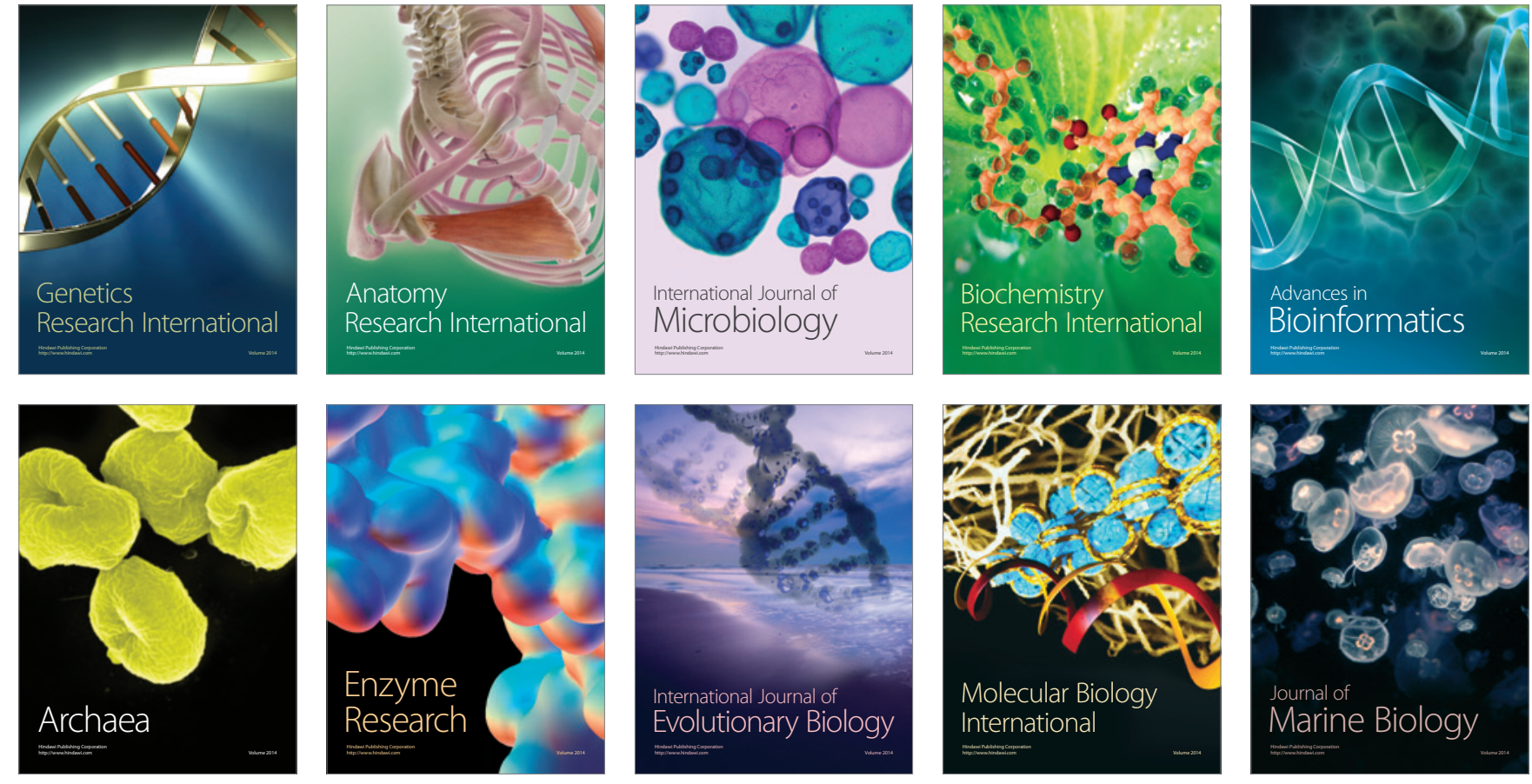